\title{
Máster en Virología Universidad Complutense de Madrid: resumen de los Trabajos Fin de Máster
}

El Máster en Virología, que se imparte en la Facultad de Veterinaria de la Universidad Complutense de Madrid, único en España especializado en esta Ciencia, ha reunido en el curso 2016-17, en su séptima edición, a 25 alumnos. Todos ellos han realizado brillantes Trabajos Fin de Máster (TFM), merecedores de ser publicados en revistas de categoría, posiblemente añadiendo algo más de trabajo de los grupos en los que se han integrado. Desde casi el comienzo de la andadura del Máster en el curso 2010-11, la Revista Complutense de Ciencias Veterinarias viene publicando los resúmenes de estos magníficos trabajos, defendidos ante sus respectivos Tribunales en las convocatorias de junio y septiembre. Los Tribunales, compuestos por virólogos de la UCM (Universidad Complutense de Madrid) y de Centros de Investigación, juzgaron los trabajos con calificaciones desde 7,0 hasta 9,7. Los temas han sido diversos. Los TFM sobre virus de bacterias [1, 5, 14, 20] han versado sobre sus aplicaciones [1], la relación virus-hospedador [5], cómo evolucionan [14] y cómo se fijan a la bacteria [20]. Los que han tratado sobre virus humanos han incluido estudios sobre el virus de la inmunodeficiencia (VIH) [4, 7, 10, 24], de las hepatitis B [15], C [22] y D (delta) [6], herpes simplex (VHS) [11], de la gripe [16], parvovirus [17] y distintos flavivirus [13]. Los TFM sobre virus animales se han centrado en el virus de la peste porcina africana (ASFV) [3, 8, 19], el de la lengua azul (BTV) [12], y el de la bursitis infecciosa aviar [23], e incluso en priones [2, 25]. Uno de los TFM ha sido sobre virus de plantas (potyvirus) [9] y uno ha sido sobre virus vaccinia y su estructura [18]. Las temáticas de los virus humanos, animales y de plantas han incluido el estudio cómo evolucionan $[4,14]$, de los mecanismos patogénicos $[2,8,9,15,16,17,23,24,25]$, la distribución de los mismos en áreas geográficas [6, 10, 13], el efecto de determinados antivirales [3, 11, 19, 22], y propuestas de antígenos vacunales [12]. Un año más, han demostrado madurez investigadora en esta apasionante ciencia.

\section{Evaluación de bacteriófagos como desinfectantes ${ }^{1}$}

\author{
Seila Agún García; Pilar García Suárez
}

Received: 5 May 2017 / Accepted: 2 October 2017

La creciente necesidad de desarrollar nuevos productos antimicrobianos que permitan la eliminación de microorganismos tanto en el ámbito alimentario como en el hospitalario, ha impulsado la investigación de los bacteriófagos. Su eficacia como agentes antimicrobianos ya ha sido demostrada en el laboratorio, pero es necesario evaluar algunos aspectos importantes antes de su aplicación a nivel industrial. Aunque se trata de productos naturales, es preciso estudiar y optimizar su aplicación. En este trabajo nos hemos centrado en antimicrobianos fágicos frente a la bacteria patógena Staphylococcus aureus, en la interacción de los mismos con desinfectantes utilizados en la industria. En concreto, se ha evaluado la sensibilidad del bacteriófago phiIPLA-RODI a distintos desinfectantes industriales, resultando este muy resistente a todos excepto al peróxido de hidrógeno. También se ha estudiado las posibles sinergias y antagonismos entre el fago y los desinfectantes. Se observó una ligera sinergia no muy significativa en el caso del triclosán y un claro antagonismo en el caso de la clorhexidina. Por último, se comprobó si el efecto antagónico de la clorhexidina se debía a un aumento de la frecuencia de mutantes insensibles al bacteriófago con resistencia cruzada al desinfectante.

Palabras clave: antimicrobianos; bacteriófago; Staphylococcus aureus; desinfectantes; clorhexidina. 


\title{
Estudio de la transmisión y propagación de diferentes cepas de alfa sinucleína en modelo de ratón transgénico ${ }^{2}$
}

\author{
Alonso Alonso, Uxía; Torres Trillo, Juan María; Fernández-Borges, Natalia
}

Recientes investigaciones describen el proceso de agregación de la proteína alfa sinucleína en las diferentes enfermedades neurodegenerativas denominadas sinucleinopatías (enfermedad de Parkinson, atrofia multisistémica y enfermedad de cuerpos de Lewy, entre otras), como un mecanismo de tipo prión (del inglés, prion-like).

El presente trabajo de fin de máster tiene como finalidad el estudio del mecanismo de transmisión y propagación de diferentes sinucleinopatías en modelo de ratón transgénico. La base del trabajo de investigación es la inoculación de ratones transgénicos PAC-Tg (SNCAWT) que expresan la alfa sinucleína humana y cuya expresión de alfa sinucleína murina ha sido anulada con tejido de cerebro de pacientes humanos afectados por la enfermedad de Parkinson, atrofia multisistémica o enfermedad de cuerpos de Lewy. A través de una cinética de sacrificio y mediante el empleo de técnicas inmunohistoquímicas pudo evaluarse el grado de transmisión y propagación de la proteína alfa sinucleína patógena en el encéfalo de estos ratones transgénicos.

Los resultados del trabajo demuestran que la proteína alfa sinucleína humana es capaz de propagarse siguiendo un modelo "tipo prión" formando agregados patológicos en las neuronas.

Palabras clave: alfa sinucleína; ratón transgénico; sinucleinopatías; transmisión; propagación; prión.

\section{Evaluación de la actividad antiviral de flavonoides frente al virus de la peste porcina africana $^{3}$}

Alonso Gutiérrez, Ana Belén; Rodríguez Gil, David

El virus de la peste porcina africana (VPPA) es el agente etiológico de una de las enfermedades más graves que afecta a los cerdos domésticos. No se dispone de vacunas eficaces, lo que implica grandes pérdidas socioeconómicas. Se ha demostrado que los flavonoides, productos naturales aislados de plantas, tienen actividad antiviral in vitro e in vivo contra diferentes virus. En este trabajo, se analiza el posible efecto antiviral de tres flavonoides, Oleuropeína, Apigenina y Hesperidina, en la infección de VPPA utilizando dos modelos celulares: células Vero y macrófagos alveolares porcinos (AMO) para establecer en ellos la máxima concentración no tóxica de cada uno de ellos para demostrar, en un estudio posterior con animales, su capacidad de proteger al hospedador frente a la PPA. La Apigenina fue el único flavonoide que demostró capacidad antiviral a las concentraciones no tóxicas en el modelo celular, mostrando buenos resultados entre 1 y $10 \mathrm{mcg}$ en las pruebas de inhibición de proteínas virales, inhibición de proliferación viral y en hemadsorción. Posteriormente se evaluó su eficacia en el tratamiento de cerdos Landrace-large White infectados con VPPA, demostrándose que a las concentraciones utilizadas, la Apigenina no impide el avance de la enfermedad en estos cerdos.

Palabras clave: VPPA; flavonoides; Oleuropeína; Apigenina y Hesperidina.

\section{Estudio de factores virales asociados a la pérdida del fenotipo LTNP en un paciente infectado por VIH-1 ${ }^{4}$}

\author{
Andrade Maldonado, Christian; Casado Herrero, Concepción; Pernas Escario, María
}

Los individuos no progresores a largo plazo (LTNPs) son una pequeña proporción de los pacientes infectados con el VIH-1. La eventual progresión de la enfermedad en estos pacientes, representa una oportunidad para el estudio de la patogénesis e identificación de determinantes implicados en el control y progresión, en un entorno inmunogenético definido. El presente estudio buscó identificar los factores virales asociados a pérdida del fenotipo LTNP en un paciente que durante más de 15 años mantuvo el control sobre la infección. El análisis filogenético de los genes env y gag mostró un aumento progresivo de la evolución a lo largo de la infección. La caracterización biológica demostró un aumento de la capacidad infectiva en las variantes recuperadas después de la pérdida del fenotipo LTNP. El análisis de Gag evidenció la presencia de mutaciones en sitios de reconocimiento HLA-A, ubicados dentro de la p24 de algunas de las

Centro de Investigación en Sanidad Animal (CISA-INIA). Valdeolmos. 28130 Madrid.

Laboratorios Diater S.A. Parque Tecnológico de Leganés. 28918. Madrid.

Instituto de Salud Carlos III. Majadahonda. 28220 Madrid. 
variantes surgidas en tiempos tardíos de la infección. Estos resultados sugieren que la pérdida del fenotipo LTNP en este paciente es el resultado de un proceso durante el cual se produjeron múltiples cambios en el genoma del VIH-1, favoreciendo su eficacia biológica y perjudicando la eficiencia de la respuesta inmune frente al virus.

Palabras clave: VIH-1; LTNP; factores virales; evolución progresiva; eficacia biológica.

\title{
Dinámica poblacional de sistemas bacteria-fago. implicaciones terapéuticas ${ }^{5}$
}

\author{
Arroyo Moreno, Sara; Lázaro Lázaro, Ester
}

Las crecientes resistencias a antibióticos suponen un gravísimo problema sanitario a nivel mundial, tanto es así, que si no se consigue una alternativa eficaz o una forma de frenar dichas resistencias, llegará la denominada "era postantibiótica" en la que una simple infección o herida podría matarnos. La terapia fágica se postula como una posible alternativa a los antibióticos convencionales. Cuando se descubrieron los bacteriófagos en el siglo XX, también empezó a emplearse este tipo de terapia, sin embargo, en la segunda mitad de siglo quedó relegada a algunos países de Europa del Este debido al descubrimiento de los antibióticos. Sin embargo, la necesidad urgente de encontrar nuevas formas de combatir infecciones bacterianas ha hecho que el interés por la misma vuelva al mundo occidental. Para realizar este tipo de terapia hay que tener conocimiento previo a cerca de cómo funcionan las dinámicas poblacionales bacteria-bacteriófago, así como las características que deben poseer los bacteriófagos para minimizar todo lo posible las poblaciones bacterianas. Este trabajo muestra que la densidad celular de partida de bacterias a infectar por el fago es muy determinante en el fitness del mismo y, por tanto, en el éxito de la terapia.

Se muestran algunas formas de mejorar la capacidad bactericida de la terapia fágica. Una de ellas es combinando el bacteriófago Q $\beta$ con un antibiótico de amplio espectro, observándose un efecto sinérgico entre ambos tratamientos. Otra posibilidad consiste en realizar pases seriados de evolución experimental del bacteriófago Q $\beta$ a densidades celulares de partida bajas, para que así se seleccionen virus mejor adaptados a estas condiciones. Finalmente se ha visto que, en efecto, el fitness del virus puede mejorar tras realizar pases seriados a densidades celulares iniciales bajas y por tanto puede aumentar su capacidad bactericida. Esta mejora puede estar relacionada con la fijación de una o dos sustituciones en la región genómica de la proteína A1.

Palabras clave: Bacteriófago Q $\beta$; dinámicas poblacionales; densidad celular bacteriana de partida; tratamiento combinado; terapia fágica.

\section{Epidemiología molecular del virus de la hepatitis Delta (VHD) en España ${ }^{6}$}

\author{
Broto Campo, Laura; Avellón Calvo, Ana
}

El virus de la hepatitis Delta (VHD) es un virus muy poco conocido. Es defectivo y co-infecta con el virus de la hepatitis B (VHB). Su genoma llama la atención por su parecido con el genoma de viroides de plantas. Los estudios de epidemiología molecular son escasos en Europa y en España no se ha hecho ninguno. El objetivo este trabajo es la realización de un estudio de epidemiología molecular del VHD en España. Se analizaron 155 secuencias obtenidas entre 2008-2016. El genotipo mayoritario con un 98,06\% fue sido VHD-1. Se detectó también VHD-5 en 1,94\%. Se han definido 8 posibles sub-genotipos dentro del VHD-1, dos de ellos lo suficientemente alejados del resto para considerar la posibilidad de que constituyan nuevos genotipos (distancia p 0,232 y 0,236 respectivamente entre ellos y el resto de secuencias del genotipo VHD-1). Se han identificado al menos 5 casos de posible transmisión directa del virus entre dos pacientes. Se ha diseñado un nuevo sistema de amplificación que permitirá en el futuro el análisis de la secuencia completa del virus.

Palabras clave: VHD; Virus de la Hepatitis Delta; epidemiología; genotipo; filogenia. 


\title{
Clinical relevance of a novel protease inhibitor resistance mechanism associated to the cytoplasmic domain of the HIV-1 envelope glycoprotein ${ }^{7}$
}

\author{
Calonge Sanz, Inés; Delgado Vázquez, Rafael
}

Virological failure in HIV-infected patients under protease inhibitor (PI)-containing antiretroviral treatment (ART) is frequently produced without resistance mutations in the protease gene. Among all the steps of the viral life cycle in which these drugs interfere, viral entry into the cell is the most strongly inhibited. Previous studies have suggested that amino acid changes in the cytoplasmic domain (CTT) from the envelope glycoprotein might be responsible of these PIsresistances in some patients. This work had the aim to characterize the clinical relevance of this resistance mechanism in PI-treated patients who undergo a prompt virological failure, without mutations in protease. The genotypic study of clones from three of these patients (infected with subtype B of HIV-1) before treatment and during the failure time point showed that the selected mutations appeared without a specific pattern among them. Results from phenotypic assays studying the infectivity of recombinant retroviral pseudotypes expressing the CTT domain fused with the remaining env gene from the reference HIV-1ADA, generated in presence or absence of lopinavir (LPV) showed nonsignificant differences in LPV-susceptibility in any of the three patients.

Keywords: Protease inhibitor; resistance; CTT domain; retroviral pseudotypes; HIV-1.

\section{Proteínas implicadas en las etapas tempranas de la infección por el virus de la peste porcina africana: decapsidación y fusión ${ }^{8}$}

Comín Polo, Jessica; Alonso Martí, Covadonga; Galindo Barreales, Inmaculada

La peste porcina africana es una enfermedad que afecta a los cerdos y que tiene una gran repercusión económica. Con el objetivo de conocer mejor el ciclo viral a nivel molecular y poder encontrar una posible vacuna o tratamiento, en el presente trabajo se clonó y expresó en el sistema de baculovirus la proteína pE248R, tentativamente implicada en la fusión del virus con el endosoma, en el sistema de baculovirus para producirla en gran cantidad y obtener anticuerpos. También se investigó el papel que juega la enzima viral E2 ubiquitín-conjugasa (UBCv) en la infección, para lo cual se realizó una extracción de fracciones ribosomales y se encontró que aparecía en las mismas fracciones que la proteína ribosomal RPS23. También se encontró colocalización nuclear de ambas proteínas en las células Vero infectadas. La expresión transitoria de UBCv se estudió en células transfectadas usando plásmidos que portaban el gen de UBCv y de UBCv mutada en el centro catalítico, pero se encontró que en ambos casos la localización era nuclear y citoplasmática, tanto en células Vero como COS. A tiempos tempranos de infección se encontró colocalización de UBCV y la proteína viral p150 en la partícula viral, lo que sugiere que UBCv sea también una proteína estructural.

Palabras clave: peste porcina africana; UBCv; pE248R.

\section{Análisis de las propiedades de los rnas pequeños asociados al supresor de silenciamiento de potyvirus HCPRO cuando se expresa en planta en ausencia de virus ${ }^{9}$}

\author{
Covielles Pérez, Eva; Canto Ceballos, Tomás
}

\begin{abstract}
Mediante secuenciación masiva hemos estudiado los RNAs pequeños (sRNAs) generados a partir de T-DNAs agroinfiltrados en Nicotiana benthamiana, en presencia del supresor de silenciamiento HCPro del potyvirus Y de la patata, y también las de sRNAs asociados a HCPro purificados de tejido infiltrado, en condiciones no desnaturalizantes. De esta manera hemos podido: 1-caracterizar la composición de las poblaciones de sRNAs presentes en tejidos agroinfiltrados, en presencia o en ausencia de un HCPro funcional; y 2-determinar características específicas de sRNAs asociados a fracciones purificadas de un HCPro funcional, como son un enriquecimiento diferencial en sRNAs de 21 nucleótidos (nt) de longitud con adeninas en su extremo 5' correspondientes a secuencias transcritas del T-DNA, pero no en sRNAs correspondientes a secuencias de la planta, de la agrobacteria, o a secuencias no transcritas del T-DNA,
\end{abstract}

Hospital Universitario 12 de octubre. 28041 Madrid.

Instituto Nacional de Tecnología Agraria y Alimentaria (INIA). 28040 Madrid.

Centro de Investigaciones Biológicas (CIB-CSIC). 28040 Madrid. 
como las promotoras. Estos resultados sugieren que HCPro funcional en supresión uniría en el citoplasma celular preferentemente sRNAs de $21 \mathrm{nt}$ con adeninas en su extremo 5', correspondientes a RNAs foráneos de tipo mensajero generados de novo, bien directamente o a través de un cofactor que los uniera. Estas uniones de HCPro podrían ser una manera de interferir la defensa antiviral basada en el silenciamiento dirigido por sRNAs.

Palabras clave: HCPro; RNAs pequeños; sRNAs; supresor de silenciamiento; resistencia a potyvirus; silenciamiento antiviral.

\title{
Análisis filogenéticos y filodinámicos de clústeres del VIH-1 recombinantes BF identificados en España ${ }^{10}$
}

Fernández Miranda, Ismael; Thomson Okatsu, Miguel

Desde la introducción del virus de la inmunodeficiencia humana tipo 1 (VIH-1), el agente causante del SIDA, en humanos en África central, este se ha expandido por diferentes áreas geográficas diversificándose en una gran variedad de formas genéticas. La generación de formas recombinantes, a partir de procesos de coinfección y superinfección, es uno de los principales mecanismos de diversificación genética del VIH-1. Algunas de las formas recombinantes del VIH-1 se han propagado epidémicamente, denominándose formas recombinantes circulantes (CRFs). En Sudamérica, la CRF que más se ha expandido es la CRF12_BF, pero también circulan otras CRFs relacionadas: CRF17_BF, CRF38 BF y CRF44_BF, identificándose múltiples formas recombinantes únicas (URFs). En este trabajo se han caracterizado tres clústeres de transmisión del VIH-1 recombinantes BF (denominados BF2, BF3 y BF5) que fueron detectados en España mediante análisis de segmentos parciales del genoma. Mediante análisis de genomas completos, se identificó una nueva CRF (CRF89_BF), correspondiente al clúster BF2, que circula principalmente en Argentina, Bolivia y España, y que está próximamente relacionada con la CRF12 BF, caracterizándose también otros dos recombinantes BF derivados de la CRF89_BF. Los análisis de genomas completos de los clústeres BF3 y BF5 evidenciaron patrones de recombinación coincidentes entre los virus de cada clúster y diferentes de las CRFs conocidas, aunque no pudieron ser designadas como nuevas CRFs, ya que, por la proximidad geográfica y temporal no se pudo descartar la relación epidemiológica entre los virus. Los análisis filogenéticos y filodinámicos permitieron estimar los orígenes geográficos y temporales de los clústeres identificados.

Palabras clave: VIH-1; recombinación genética; forma recombinante circulante; clúster de transmisión; filodinámica.

\section{Determinación de la eficacia de los candidatos a vacuna rMVA-NS1-Nt y rMVA-152 frente al virus de la lengua azul en ratones IFNAR $(-/-)^{11}$}

\author{
García Álvarez, Carlos Andrés; Ortego Alonso, Francisco Javier; Calvo Pinilla, Eva; Marín López, Alejandro
}

El virus de la lengua azul (BTV) es un Orbivirus prototipo de la familia Reoviridae, el cual posee un genoma de ARN segmentado de doble cadena y causa una enfermedad grave en rumiantes domésticos y salvajes. Este virus es responsable de grandes pérdidas económicas alrededor del mundo, por lo que la implementación de medidas eficaces como la vacunación, han resultado de gran importancia para el control de la enfermedad. Las vacunas comerciales actuales no confieren protección multiserotipo, lo que ha dado lugar a diversas investigaciones con vacunas recombinantes, por las cuales se ha demostrado que la proteína NS1 desencadena una protección celular heteróloga frente al virus. En este trabajo se quiso determinar la mínima parte de la proteína que induce inmunidad. Se generaron dos MVAs recombinantes (rMVAs), uno con el fragmento amino-terminal de NS1 (rMVA-NS1-Nt) y otro con el péptido inmunogénico 152 (rMVA-152), para probarlos como candidatos vacunales en ratones IFNAR (-/-). La inmunización con rMVA-NS1-Nt confirió una protección homóloga y heteróloga, con una respuesta T CD8+ protectora; lo que no ocurrió con el rMVA152. Se propone que rMVA-NS1-Nt tiene un futuro prometedor como vacuna generadora de protección multiserotipo, debiendo ser ensayada en un hospedador natural del virus.

Palabras clave: Virus de la lengua azul; fragmento amino-terminal (Nt) de NS1; péptido 152; virus vaccinia Ankara modificado; vacuna. 


\title{
Caracterización de la reactividad cruzada serológica de flaivirus co-circulantes en Europa ${ }^{12}$
}

\author{
García Irazábal, Alberto; Jiménez Clavero, Miguel Ángel; Llorente de Gracia, Francisco
}

Una particularidad de las técnicas de diagnóstico serológico, dentro de los miembros del género flavivirus, es la existencia de un alto grado de reactividad cruzada, limitando la especificidad de estas técnicas. La existencia de distintos flavivirus co-circulando en la misma área podría llevar a un diagnóstico erróneo, resultando por ello de interés profundizar en el conocimiento y alcance del problema con el objeto de incrementar la especificidad de las mismas. En el presente trabajo se ha caracterizado la reactividad cruzada en las pruebas de diagnóstico serológico de los flavivirus transmitidos por mosquitos co-circulantes en Europa: virus West Nile (WNV), virus Usutu (USUV) y virus Bagaza (BAGV). Los análisis se llevaron a cabo para las técnicas de enzimoinmunoensayo (ELISA) y micro virus-neutralización (micro-VNT) utilizando muestras de animales infectados experimentalmente obtenidos en el laboratorio en estudios previos. Se observó reactividad cruzada serológica no solo entre WNV y USUV, pertenecientes al mismo serocomplejo, sino entre WNV y BAGV, y entre USUV y BAGV, pertenecientes a diferentes serocomplejos. Mediante micro-VNT se observó una elevada detección específica de anticuerpos frente a WNV, moderada frente a BAGV y reducida frente a USUV. Este hecho podría hacer que se subestime la prevalencia de la infección por USUV y en menor medida por BAGV en los planes de vigilancia epidemiológica.

Palabras clave: Flavivirus; Virus West Nile; Virus Usutu; Virus Bagaza; Reactividad cruzada.

\section{Adaptación del bacteriófago $\mathrm{q} \beta$ a replicar en bacterias de fase exponencial tardía ${ }^{13}$}

\author{
García Sáez, Pedro; Lázaro Lázaro, Ester
}

La mayoría de los estudios sobre la interacción bacteria-bacteriófagos realizados en el laboratorio utilizan bacterias que están en fase de crecimiento exponencial que es en las que el fago replica de forma más óptima. Por lo tanto es necesario entender como los bacteriófagos persisten en la naturaleza, cuando infectan bacterias en otras fases de crecimiento. Para ello hemos caracterizado el ciclo infeccioso del bacteriófago Q $\beta$ utilizando bacterias en fase de crecimiento exponencial, exponencial tardía, y estacionaria temprana. Hemos realizado experimentos de replicación en un solo ciclo para determinar el crecimiento intracelular, y otros para determinar la adsorción. Este virus también ha sido sometido a evolución experimental, tanto exponiéndolo directamente a bacterias de fase exponencial tardía, como gradualmente, mediante el uso de mezclas de bacterias de distintas fases. Los resultados muestran que el bacteriófago Q $\beta$ madura más lentamente al aumentar la edad de las bacterias. El virus no pudo mantenerse en bacterias de fase exponencial tardía, mientras que sí pudo hacerlo cuando una fracción de las bacterias era de menor edad. Las líneas evolucionadas en los experimentos de adaptación gradual presentan un aumento en la capacidad replicativa y varias mutaciones, probablemente beneficiosas, que permiten al bacteriófago replicar en estas condiciones.

Palabras clave: Bacteriófago Qß; Stochasticity; Fase estacionaria; Coevolución bacteria-virus; Colifagos.

\section{Generación de líneas celulares deficientes y de sobreexpresión de aquarius y senataxin para el estudio de la infección por el virus de la hepatitis $\mathrm{B}^{14}$}

\author{
Gómez Moreno, Andoni; Garaigorta de Dios, Urtzi
}

La infección por el virus de la hepatitis B (VHB) es la principal causa de hepatitis aguda y crónica, cirrosis hepática y carcinoma hepatocelular. Alrededor de 240 millones de personas están crónicamente infectadas por el VHB. La persistencia del VHB está mediada por el ADN viral episomal denominado cccDNA que funciona como molde para la transcripción de los ARNs mensajeros virales (ARNm). Los tratamientos utilizados en clínica, inhiben etapas tardías del ciclo del VHB, sin afectar a los niveles de cccDNA ni a la transcripción de los ARNm virales a partir del mismo. La formación de cccDNA depende de factores celulares, por lo que el conocimiento de los distintos factores celulares implicados en la formación, metabolismo y modulación de la expresión del cccDNA puede aportar estrategias terapéuticas para el tratamiento curativo de la hepatitis B. Experimentos de cribado genético de nuestro laboratorio han identificado Aquarius y Senataxin, como factores celulares restrictivos de la infección por el VHB. En este trabajo

Centro de Investigación en Sanidad Animal (CISA-INIA). Valdeolmos. 28130 Madrid.

Instituto Nacional de Tecnología Aeroespacial (INTA). 28850 Torrejón de Ardoz.

Centro Nacional de Biotecnología (CNB). Campus de Cantoblanco. 28049 Madrid. 
de fin de máster se pretende generar líneas celulares deficientes y que sobreexpresen ambos factores mediante edición genómica con CRISPR/Cas con el fin de validar nuestros experimentos y caracterizar en el futuro la función de dichos factores en la infección.

Palabras clave: VHB; cccDNA; Aquarius; Senataxin; y CRISPR/Cas.

\title{
Patogenicidad de virus de la gripe mediada por infección cardíaca y su posible relación con la producción de genomas virales defectivos (DVGS) $)^{15}$
}

\author{
Gutiérrez García, Celia; Falcón Escalona, Ana
}

Durante la gripe pandémica del 2009, alrededor del 10\% de los pacientes desarrollaron complicaciones cardíacas asociadas a la infección por el virus AH1N1pdm09. A partir de la caracterización in vivo e in vitro de dos aislados clínicos circulantes durante este período, uno proveniente de un paciente fallecido (F) y otro que había padecido síntomas leves (M), se comprobó que la mutación responsable del aumento de patogenicidad en $\mathrm{F}$ es la que afecta a la subunidad PA de la polimerasa viral. Ésta le permite replicar de forma más activa en tejido cardíaco y produce alteraciones en el ritmo cardíaco en modelo murino. El objetivo de este trabajo es determinar la capacidad de diferentes virus de la gripe para infectar células cardíacas en cultivo. Se ha comprobado que el subtipo H1N1 replica de forma más eficaz que otros en este tipo celular. Además, los virus caracterizados previamente como más patogénicos in vivo presentan en células cardíacas en cultivo una cinética de infección más rápida y menor acumulación de genomas virales defectivos que los más atenuados. Por tanto, se ha demostrado que virus con mutaciones que afecten a la polimerasa podrían provocar disfunciones cardíacas durante la infección que influyan en el desenlace de la enfermedad.

Palabras clave: gripe; disfunciones cardíacas; genomas virales defectivos.

\section{Role of non-structural proteins of the parvovirus MVMI in human transformed cells ${ }^{16}$}

\author{
Lavega González, Rebeca; Almendral del Río, José María
}

\begin{abstract}
Aimed at understanding parvovirus oncolytic potential, we have studied the nuclear transport of the structural (VPs) and nonstructural (NSs) proteins of the mouse parvovirus MVMi and of a T/A engineered mutant, in different transformed cells under several cell cycle arrest methods. We observed that the MVMiT/A mutant showed, in respect to the wtMVMi strain, altered NSs nuclear transport and enhanced nuclear capsid assembly in cells released from cell cycle arrests. Interestingly, these regulations differed between human glioblastoma cell lines with disparate permissiveness to MVM infection. In addition, we report that MVMiT/A induced an up- regulation of the MAPK pathway, as demonstrated by the appearance of novel p-ERK isoform. These data do support the potential oncolytic capacity of this virus. Further analyses into the mechanisms involving nuclear transport and MAPK signaling upregulation will be required to exploit the MVM oncolytic potential.
\end{abstract}

Keywords: Minute Virus Mice (MVMi); Parvovirus; Non-structural proteins; MAPK pathway; Oncolytic virotherapy.

\section{Cryo-X-ray tomography of viral factories in vaccinia virus-infected cells ${ }^{17}$}

\author{
Moreno Serrano, José; López Carrascosa, José
}

VV (vaccinia virus) is one of the most complex viruses, with a size exceeding $300 \mathrm{~nm}$ and more than 100 structural proteins. Its assembly involves sequential interactions and important rearrangements of its structural components. In this study, the infected cells were selected by light fluorescence microscopy of and subsequently imaged in the X-ray microscope under cryogenic conditions. Tomographic tilt series of X-ray images were used to yield three-dimensional reconstructions showing different cell organelles (nuclei, mitochondria, ER), together with other two types of viral particles related to different maturation steps of vaccinia virus (IV) immature and (MV) mature particles; and assays with witaferin showed binds with actin that prevents its polymerization and elongation of filaments; causing badly

15 Centro Nacional de Biotecnología (CNB). Campus de Cantoblanco. 28049 Madrid.

16 Dpto. Virología y Microbiología, Centro de Biología Molecular Severo Ochoa. Campus de la Universidad Autónoma. 28049 Madrid.

17 Centro Nacional de Biotecnología (CNB). Campus de Cantoblanco. 28049 Madrid. 
packed or aberrant virions, the progression of viral infection is inhibited. The findings show that cryo X-ray tomography is a powerful tool for collecting three-dimensional structural information from frozen, unfixed, unstained whole cells with sufficient resolution to detect different virus particles exhibiting distinct maturation levels.

Keywords: Vaccinia virus; cryo-X-ray tomography; viral factory; actin filaments.

\title{
Inhibidores de fusión de lípidos de membrana como compuestos antivirales contra el virus de la peste porcina africana (VPPA) ${ }^{18}$
}

Náñez Cabrero, Almudena; Alonso Martí, Covadonga; Galindo Barreales, Inmaculada

Las envueltas de los virus son bicapas lipídicas metabólicamente inertes que muestran una curvatura específica, concretamente, positiva. La membrana celular externa está formada por fosfolípidos que también favorecen la curvatura positiva. Sin embargo, durante el desarrollo de la fusión se necesita una curvatura local de membrana negativa. Esta característica permite la correcta fusión de las partículas virales a membranas celulares y, dado que es un proceso único y esencial para llevar a cabo la infección, se ha considerado su bloqueo como diana terapéutica. Se ha descubierto que el enriquecimiento en fosfolípidos con grandes cabezas hidrofílicas y colas hidrofóbicas cortas en la membrana externa de vesículas favorece la curvatura positiva y, por tanto, aumenta la barrera energética de activación del proceso dando lugar a la inhibición de la fusión viral. Dado que los fosfolípidos no tienen uso farmacológico, se han diseñado moléculas sintéticas con una forma similar que permitan imitar este suceso en la célula: inhibidores rígidos anfipáticos de fusión (IRAFs). En el presente trabajo, se evaluará la efectividad de 4 IRAFs diferentes frente al virus de la Peste porcina africana, un virus que usa ampliamente el sistema de membranas de la célula para llevar a cabo su ciclo vital, con el objetivo de caracterizar el proceso y testar la efectividad de estos agentes como antivirales.

Palabras clave: VPPA; IRAFs; antivirales; fusión.

\section{Analysis of T7 phage GP17 fiber protein and its binding with LPS ${ }^{19}$}

\author{
Pagalday Arrizabalaga, Laida; Van J. Raaij, Mark; Sanz Gaitero, Marta
}

Bacteriophage T7 is a member of the Podoviridae family, and has six fibers formed of trimers of gp17 that interact with the host. This interaction occurs in the C-terminal region of the fibers. A detailed mechanism about how adsorption occurs between T7 phage and E.coli has not been described yet. The objectives of this study are to crystalize gp 17.371 with its ligand and on the other hand, identify if mutations at selected amino acids on the fiber affect the infectivity of the phage. A purification of the protein gp17.371 has been performed, for a future crystallization with the corresponding ligand. On the other hand, complementation assays have been performed in order to evaluate the implication of selected amino acids in bacterial infection. Mutants were achieved by mutagenic PCRs using designed primers to produce specific mutants in the following amino acids: N501H, R542H, and a double mutant R543, V544A. We demonstrate that His-tag hinders crystallization of the gp17.371 protein. However, the protein ligand interaction region still needs to be solved. On the other hand, complementation assays showed that mutant fibers decrease the infectivity of the T7 phage in top 10 cells, however more assays need to be done.

Keywords: T7 bacteriophage; crystallography; fiber; gp17; purification; receptor.

\section{Estudio de los mecanismos de escape al favipiravir durante la replicación de virus de la hepatitis $\mathrm{C}$ de distinto fitness en cultivos ${ }^{20}$}

Rodríguez de Gaspar Fernández, Jose Luis; Domingo Solans, Esteban; Perales Viejo, Celia

El virus de la hepatitis $\mathrm{C}(\mathrm{HCV})$ representa un grave problema para la salud mundial. Actualmente existen tratamientos eficaces contra la infección, pero debido a que se trata de un virus RNA, desarrolla rápidamente resistencias a éstos, lo que hace necesario buscar nuevas terapias. Estudios con varios sistemas virus-hospedador en cultivos celulares han establecido que el aumento de la tasa de error durante la replicación viral, promovido por análogos de nucleótido, puede conducir a la extinción de virus, siendo ésta la base de la mutagénesis letal como terapia antiviral. Recientemente se ha documentado que el favipiravir es un potente agente mutagénico frente a HCV (clon inicial denominado HCV p0)

\footnotetext{
Instituto Nacional de Tecnología Agraria y Alimentaria (INIA). 28040 Madrid.

Centro Nacional de Biotecnología (CNB). Campus de Cantoblanco. 28049 Madrid.

Centro de Biología Molecular Severo Ochoa. Campus de la Universidad Autónoma. 28049 Madrid.
} 
durante su replicación en cultivos celulares mientras que un virus de alto fitness (HCV p200, virus HCV p0 sometido a 200 pases seriados en cultivos celulares) presenta una resistencia parcial al fármaco. El objetivo del presente trabajo es analizar la posible vía de escape mediante la aparición de mutaciones de resistencia durante la adaptación del HCV p0 y HCV p200. En este trabajo, se vio que HCV p0 muestra cierta resistencia al fármaco, posiblemente debida a la sustitución A488V encontrada en la polimerasa, en los pases 20 y 30 . El mecanismo de resistencia a drogas que opera en el HCV p200 podría estar relacionado con un nuevo mecanismo de resistencia basado en su alta capacidad replicativa o fitness.

Palabras clave: hepatitis C; virus; fitness; favipiravir; mutagénesis letal; resistencia.

\title{
Establecimiento y caracterización infecciones persistentes por el virus de la bursitis infecciosa aviar ${ }^{21}$
}

\author{
Romero Rata, Nicolás; Rodríguez Aguirre, José Francisco
}

Infectious bursal disease virus (IBDV), a highly relevant avian pathogen, belonging to the Birnaviridae, a family grouping naked icosahedral viruses harbouring bipartite dsRNA genomes, but lacking an inner transcriptional core structure. IBDV is generally regarded as a strict cytolytic virus, causing the destruction of all infected cells. In contrast to this notion, data from our laboratory conclusively shows that a reduced, yet significant fraction of IBDV-infected cell populations survive the acute IBDV infection phase. After recovering from the initial virus-induced stress, surviving cells readily divide, generating healthy-looking cultures continuously shedding infectious IBDV. Although we have successfully generated persistently-infected cultures derived from cell lines of different origins (avian and mammalian), most our work has been performed using DF1 (immortalized chicken embryo fibroblasts; ATCC CRL-12203) cells. We are keen in deciphering the mechanism(s) allowing the establishment of IBDV persistent infections, thus our work has been mainly focused on the characterization of both persistently-infected DF1 cells and IBDV isolates recovered from these cultures. Our data indicates that both the expression of virus-encoded proteins and IBDV genome copy numbers undergo a progressive decline associated to the duration of the persistent infection. Studies performed using 90 days post-infection cultures show that although susceptible to infection to a variety of RNA and DNA viruses, persistently-infected DF1 cells are refractory to IBDV superinfection, as determined by RT-qPCR, Western blotting and immunofluorescence analyses. Experiments using purified IBDV virus like particles and infectious virus indicate that this restriction takes place after the release of the virus genome to the cell cytoplasm. We have analysed the status of the innate antiviral response of persistently-infected cells. Gathered data show that, although efficiently secreting IFN in response to addition of exogenous dsRNA, persistently-infected cells are completely unresponsive to IFN treatment, thus indicating the arrest of the JAK-STAT signalling pathway. On the other hand, the replication ability of isolates recovered from persistently-infected cultures does not differ from that of the wild-type virus, as determined by immunofluorescence, virus titration and RT-qPCR analyses. Ongoing NGS of persistent viral populations and comparative transcriptome analyses of naïve and persistently-infected DF1 cells should shed light to understanding the mechanism(s) allowing the establishment of IBDV persistent-infections. This newly described experimental system offers a promising venue to studying the complex set of IBDV-host cell interactions.

Keywords: IBDV; persistent infection; innate antiviral response.

\section{Especificidad de corte de la RNASA H del VIH-1 y el VIH-2 sobre complejos portadores de secuencias ricas en purina (PPTS) y papel de los aminoácidos del subdominio Connection de la transcriptasa reversa ${ }^{22}$}

\author{
Sapena Ventura, Enrique; Menéndez Arias, Luis
}

En retrovirus, las retrotranscriptasas (RTs) son enzimas responsables de la replicación de su genoma. Son ADN polimerasas con actividad ribonucleasa $\mathrm{H}$ que convierten el ARN genómico de cadena sencilla en ADN de cadena doble. Durante la síntesis de la cadena positiva de ADN se utiliza como iniciador un fragmento no degradado del ARN viral, rico en purinas y denominado PPT (polypurine tract). Este iniciador ha de ser eliminado durante el proceso, fenómeno que debe ocurrir de forma precisa. Se han empleado variantes de la RT del VIH-1 y del VIH-2, silvestres y portadoras de cambios de aminoácido en el subdominio connection, para determinar cómo influiría su actividad RNasa H sobre el procesamiento de los PPTs. Observamos diferencias entre las RTs del VIH-1 y VIH-2, si bien el procesamiento de PPTs por RTs de grupos distintos del VIH-1 fue similar. Las sustituciones de aminoácido N348I/ T369I disminuyen la eficacia del procesamiento de PPTs y su actividad no se ve afectada por mutaciones de resistencia

21 Centro Nacional de Biotecnología (CNB). Campus de Cantoblanco. 28049 Madrid.

22 Centro de Biología Molecular Severo Ochoa. Campus de la Universidad Autónoma. 28049 Madrid. 
a fármacos antirretrovirales. El cambio E399G revierte parcialmente los efectos de N348I. Sin embargo, cambios que aumentan la afinidad de la RT de VIH-1 grupo O por complejos molde-iniciador no alteran su especificidad de corte.

Palabras clave: VIH-1; VIH-2; Transcriptasa reversa; tracto de polipurinas; subdominio connection.

\title{
ESTUDIO DE LA DIVERSIDAD DE CEPAS DE SCRAPIE EN MODELOS IN VITRO 23
}

\author{
Zamora Ceballos, María; Torres Trillo, Juan María; Espinosa Martín, Juan Carlos
}

El scrapie es una Encefalopatía Espongiforme Trasmisible presente en rebaños de pequeños rumiantes desde hace cientos de años. En un trabajo previo del laboratorio se caracterizaron las propiedades biológicas de una colección de aislados de scrapie, procedentes de distintos países europeos, utilizando ratones transgénicos. Este trabajo permitió concluir la existencia de al menos cuatro grupos de aislados con características fenotípicas diferentes. Aprovechando el material biológico generado en ese estudio, ahora se pretende desarrollar un método efectivo, sensible y rápido para la tipificación de cepas de scrapie combinando el ensayo CSSA (Conformational Solubility and Stability Assay) y la PMCA (Protein Misfolding Cyclic Amplification). Para ello, se seleccionaron aislados de scrapie representativos de cada grupo previamente definido en el bioensayo. El estudio de la capacidad de amplificación de la PrPSc en PMCA permitió diferenciar algunos aislados seleccionados. Sin embargo, el ensayo CSSA no diferenció ningún aislado ni en material propagado in vivo (ratón) ni in vitro (PMCA). Los resultados de la combinación de PMCA y CSSA ponen de manifiesto que aunque esté método en su estado actual no permite la tipificación y discriminación rápida de cepas de priones, optimizando algunos aspectos del mismo podría convertirse en una buena herramienta para la discriminación de cepas.

Palabras clave: prion; scrapie; cepa; CSSA; conformación proteica. 